\title{
DNA barcoding based on plastid matK and RNA polymerase for assessing the genetic identity of date (Phoenix dactylifera L.) cultivars
}

\author{
M.R. Enan ${ }^{1,2}$ and A. Ahmed ${ }^{1}$ \\ ${ }^{1}$ Biology Department, College of Science, \\ United Arab Emirates University, United Arab Emirates \\ ${ }^{2}$ Agricultural Research Center, \\ Agricultural Genetic Engineering Research Institute, Giza, Egypt \\ Corresponding author: M.R. Enan \\ E-mail: mohamed.enan@uaeu.ac.ae
}

Genet. Mol. Res. 13 (2): 3527-3536 (2014)

Received May 17, 2013

Accepted October 30, 2013

Published February 14, 2014

DOI http://dx.doi.org/10.4238/2014.February.14.2

\begin{abstract}
The cultivated date palm is the most agriculturally important species of the Arecaceae family. The standard chloroplast DNA barcode for land plants recommended by the Consortium for the Barcode of Life plant working group needs to be evaluated for a wide range of plant species. Therefore, we assessed the potential of the matK and $r p o \mathrm{C} 1$ markers for the authentication of date cultivars. There is not one universal method to authenticate date cultivars. In this study, 11 different date cultivars were sequenced and analyzed for mat $\mathrm{K}$ and $r p o \mathrm{Cl}$ genes by using bioinformatic tools to establish a cultivarspecific molecular monogram. The chloroplast matK marker was more informative than the rpo $\mathrm{Cl}$ chloroplast DNA markers. Phylogenetic trees were constructed on the basis of the matK and $r p o \mathrm{C} 1$ sequences, and the results suggested that mat $\mathrm{K}$ alone or in combination with $r p o \mathrm{C} 1$ can be used for determining the levels of genetic variation and for barcoding.
\end{abstract}

Key words: Arecaceae; Barcoding; Phoenix dactylifera; matK; rpoC1 


\section{INTRODUCTION}

Phoenix dactylifera L. $(2 \mathrm{n}=36)$ is a dioecious perennial crop belonging to the Arecaceae family and commonly known as date palm. It is widely cultivated in many countries extending from North Africa to the Middle East, including many states of the Arabian Gulf Cooperation Countries. Many date cultivars, owing to their diverse therapeutic properties, are utilized in traditional medicine (Bulpitt et al., 2007; Sghaier-Hammami et al., 2009). Date palms are also used as sources of food, farm income, and other products for local desert dwellers. All parts of the date tree are used for various industrial purposes. The extracts of date fruits have been reported to have biologically active antioxidants and antimutagenic activities (Biglari et al., 2008; Saafi et al., 2009).

The term DNA barcode was first coined by Hebert et al. (2003) and has gained worldwide attention in the scientific community (Chen et al., 2010). Currently, chloroplast DNA markers are used for the accurate identification and authentication of plant species (Chase et al., 2005; CBOL Plant Working Group, 2009; Devey et al., 2009; Fazekas et al., 2009; Chen et al., 2010; Al-Qurainy et al., 2011a). Variations in DNA sequences are very helpful in the development of unique markers, which can be used as a DNA barcode for that species. Many loci from the plastid genome, including $r b c L, r p o B, r p o \mathrm{C} 1, t r n H-p s b A$ spacer, and $m a t \mathrm{~K}$, have been tested for DNA barcoding of plants with different degrees of success (Kress et al., 2005; Lahaye et al., 2008; Hollingsworth et al., 2011). Thus far, no consensus sequence has been identified as a universal barcode in land plants. For the accurate and reproducible identification of species, analysis of more than one locus would be required (Kress et al, 2005; Kress and Erickson, 2007; Lahaye et al., 2008; Fazekas et al., 2008; CBOL Plant Working Group, 2009). Sequencing- and non-sequencing-based markers have been used in many medicinal and non-medicinal plant species for the detection of adulterants in the local herbal markets (Khan et al., 2011; Al-Qurainy et al., 2011b). CBOL Plant Working Group (2009) recommended two-locus combination of matK and $r b c l$ as the plant barcode. The morphological as well as biochemical markers used in the identification of plant species have many limitations due to their low reproducibility. Moreover, visually differentiating seeds of different species is difficult (Khan et al., 2011). Therefore, the main objective of this study is to assess the efficiency of 2 loci, mat $\mathrm{K}$ and $r p o \mathrm{C} 1$, as barcodes for the precise authentication of date cultivars.

\section{MATERIAL AND METHODS}

\section{Plant material}

Eleven date samples were collected from Al Ain city, United Arab Emirates. Plant material consisted of young leaves sampled from adult trees (Table 1). Leaf samples were individually placed in plastic pouches and transported to the laboratory and stored at $-80^{\circ} \mathrm{C}$ until processing for DNA extraction.

\section{DNA extraction}

Leaf samples were immersed in liquid nitrogen and crushed using sterile mortar and pestle to obtain a fine powder. DNeasy plant mini kit (Qiagen, Germany) was used for DNA 
isolation. The quality of the extracted DNA was determined using gel electrophoresis and Nanodrop 2000 spectrophotometer (Thermo Scientific, USA).

\begin{tabular}{|c|c|c|c|c|c|c|}
\hline \multirow[t]{2}{*}{ Cultivars } & \multirow[t]{2}{*}{ Abbreviation } & \multicolumn{2}{|c|}{ matK } & \multicolumn{3}{|c|}{$r p o \mathrm{C} 1$} \\
\hline & & Locality & Accession No. & $\mathrm{G}+\mathrm{C}(\%)$ & Accession No. & $\mathrm{G}+\mathrm{C}(\%)$ \\
\hline AbuMaan & PD1 & Al Ain, UAE & KC437393 & 33.8 & КС793979 & 42.1 \\
\hline Ngal & PD2 & Al Ain, UAE & KC771273 & 34.5 & - & - \\
\hline Fard & PD4 & Al Ain, UAE & KC437392 & 34.5 & KC793975 & 42.2 \\
\hline Khenezi & PD5 & Al Ain, UAE & KC437387 & 34.5 & KC793976 & 42.2 \\
\hline Khalas & PD6 & Al Ain, UAE & KC437389 & 34.5 & КC793980 & 46.2 \\
\hline Khalasuae & PD7 & Al Ain, UAE & KC771274 & 30.4 & KC793978 & 42.5 \\
\hline Gashzabad & PD8 & Al Ain, UAE & KC437394 & 33.8 & KC793972 & 42.2 \\
\hline Hilali & PD9 & Al Ain, UAE & KC437390 & 34.5 & KC793974 & 42.2 \\
\hline Nmishi & PD10 & Al Ain, UAE & KC437388 & 34.5 & KC793973 & 42.2 \\
\hline Barhi & PD11 & Al Ain, UAE & KC771272 & 34.8 & - & - \\
\hline Jaberi & PD12 & Al Ain, UAE & KC437391 & 34.5 & KC793977 & 42.2 \\
\hline
\end{tabular}

$(-)=$ sequencing of PCR products failed.

\section{Amplification of the matK and rpoC1 genes}

A total volume of $25 \mu \mathrm{L}$ of PCR mixture contained the following: $12.5 \mu \mathrm{L}$ Taq PCR Master Mix (Qiagen), yielding a final concentration of $200 \mu \mathrm{M}$ of each deoxynucleotide and $1.5 \mathrm{mM} \mathrm{MgCl}, 1 \mu \mathrm{M}$ of each primer (Table S1; Eurofins MWG Operon, Germany), $2 \mu \mathrm{L}$ (50 ng) genomic DNA, and the rest was adjusted with sterile distilled water. PCR amplification was performed using a T100 thermal cycler (BioRad, USA) as follows: $95^{\circ} \mathrm{C}$ for $1 \mathrm{~min}$, followed by 35 cycles of $95^{\circ} \mathrm{C}$ for $30 \mathrm{~s}, 50^{\circ} \mathrm{C}$ for $30 \mathrm{~s}$, and $72^{\circ} \mathrm{C}$ for $60 \mathrm{~s}$, followed by an elongation step at $72^{\circ} \mathrm{C}$ for $5 \mathrm{~min}$. All PCR conditions were used as described previously (Sass et al., 2007; Yu et al., 2011). The universal primers for the 2 loci are listed in Table S1.

\section{Agarose gel electrophoresis}

A long $(14 \times 11 \mathrm{~cm}) 1.5 \%$ agarose gel in $1 \mathrm{X}$ TBE buffer containing $0.5 \mu \mathrm{g} / \mathrm{mL}$ ethidium bromide was used for electrophoresis of the PCR products. Gel images were obtained using gel document (Major Bioscience, Taiwan) UV transilluminator imaging system. The sizes of the PCR products resulting from the primer pairs of the specific barcoding gene were determined using a 100-bp ladder (Qiagen) and Un-Scan-It gel version 6.1 (Silk Scientific Inc., USA).

\section{DNA sequencing and data analysis}

The sequencing reaction was performed using a BigDye Terminator cycle sequencing kit (Perkin-Elmer, Applied Biosystems) according to manufacturer instructions for the ABI PRISM 310 DNA Analyzer (Perkin-Elmer, Applied Biosystems). All sequences generated in the present study were deposited in GenBank for reference; their accession numbers are provided in Table 1. The Basic Local Alignment SearchTool (BLAST) was used to detect ho- 
mologous sequences to those obtained for date cultivars. When the sequences were confirmed to be mat $\mathrm{K}$ and rpoC1, phylogenetic trees were inferred with the maximum likelihood (ML), neighbor-joining tree (NJ), and UPGMA methods. The topologies of the phylogenetic trees were evaluated using the bootstrap resampling method with 1000 replicates. Codon positions included were $1 \mathrm{st}+2 \mathrm{nd}+3 \mathrm{rd}+$ noncoding. Pairwise distance, transitional/transversional substitutions, and phylogenetic analyses were conducted using MEGA5.0 (Tamura et al., 2004, 2007). Genetic variation among date cultivars was estimated by calculating the number of polymorphic sites and mutations, haplotype diversity, and nucleotide diversity by using the DnaSP software (Librado and Rozas, 2009).

\section{RESULTS AND DISCUSSION}

The main objective of this study was to amplify and characterize two loci rpoC1 and matK from the chloroplast genome to assess their suitability for the resolution of date cultivars. Electrophoretic analysis of PCR products based on partially amplified matK and rpoC1 genes resulted in a single amplified DNA band. In a previous study, the rpoC1 locus was not successfully amplified from the date palm cultivars (Al-Quariny et al., 2011a). The amplification of matK was not problematic, as suggested by Kress and Erickson (2007).

The phylogenetic relationships among the date palm cultivars have been evaluated in different countries such as Tunisia, USA (California), and Morocco by using various conventional molecular markers such as ISSR, AFLP, RAPD (Sedra et al., 1998; Al-Khalifah and Askari, 2003; Elshibli and Korpelainen, 2008), and microsatellites (Zehdi et al., 2004; Elshibli and Korpelainen, 2008). These markers showed high polymorphism among the date palm cultivars, but were ineffective in characterizing them. Genetically, the date palm is highly diverse due to existence of large number of cultivars distributed across different habitats (Khan et al., 2011). The chloroplast genome has been used successfully for the identification of various cultivars of date palm in Saudi Arabia (Al-Qurainy et al., 2011a). In this study, 3 phylogenetic methods were applied using one barcode locus or in combinations to evaluate the recovery of cultivars. When all the sequences for a given locus were considered, mat $\mathrm{K}$ could form cultivarspecific clusters. A single cultivar, Khalasuae (United Arab Emirates) was recovered as a single genotype in the first cluster. Figures 1, 2, and Figure S1 show phylogenetic trees constructed by using UPGMA, ML, and NJ, respectively; the second cluster consisted of Gashzabad and Abu Maan. All the remaining cultivars were included in the third cluster that had 2 sub-clusters: the first sub-cluster included khalas (Saudia Arabia), Nmishi, Hillali, Fardi, Jaberi, Ngal, and $B a r h i$, and the second sub-cluster included Khenezi. The cultivar-specific clusters in matK trees resolved with high bootstrap confidence levels (95-100\%) by using UPGMA and NJ, while, with ML, the bootstrap levels were 76-100\%. In $r p o \mathrm{C} 1$ trees constructed by using UPGMA, ML, and NJ, as shown in Figures 3, 4, and Figure S2), khalas (Saudia Arabia) and Abu Maan were placed in the first cluster, whereas the second cluster included Gashzabad, Nmishi, Khene$z i$, Jaberi, Hillali, Fardi, and Ngal; Khalasuae was included in a separate sub-cluster. Bootstrap confidence levels were $88-100 \%$ with $r p o C 1$ barcode when all 3 phylogenetic methods were used. ML showed the same tree topology as UPGMA and NJ with single locus analysis for the recovery of date cultivars. It can be assumed that, if different methods yield the same tree, then a robust estimation will become possible (Hosseini et al., 2012). The mat K locus provided better cultivar recovery compared to rpoC1. We compared the performance of combined mat $\mathrm{K}+$ 
rpoC1 barcodes by using unweighted pair group (Figure 5), ML (Figure 6), and NJ (Figure S3) methods; the results indicated that there was no marked increase in the recovery of cultivars. In a recent study, the rpoC1 marker exhibited the lowest level of resolution among the evaluated regions (matK $>a t p F-a t p H>r b c L>t r n H-p s b A>r p o \mathrm{C} 1$; Burgess et al., 2011). Phylogenetic methods were applied in a recently conducted study of barcoding species by using each barcode locus alone or in combination with others to evaluate species recovery (Roy et al., 2010). The mat $\mathrm{K}$ region has been used to construct the phylogeny of legumes and species belonging to the Fabaceae family (Wojciechowski et al., 2004; Gao et al., 2011). In a previous study, rpoC1 and psbA trn $H$ GUG $n d h F$ were used to construct the phylogeny of the genus Lathyrus (Asmussen and Liston, 1998).
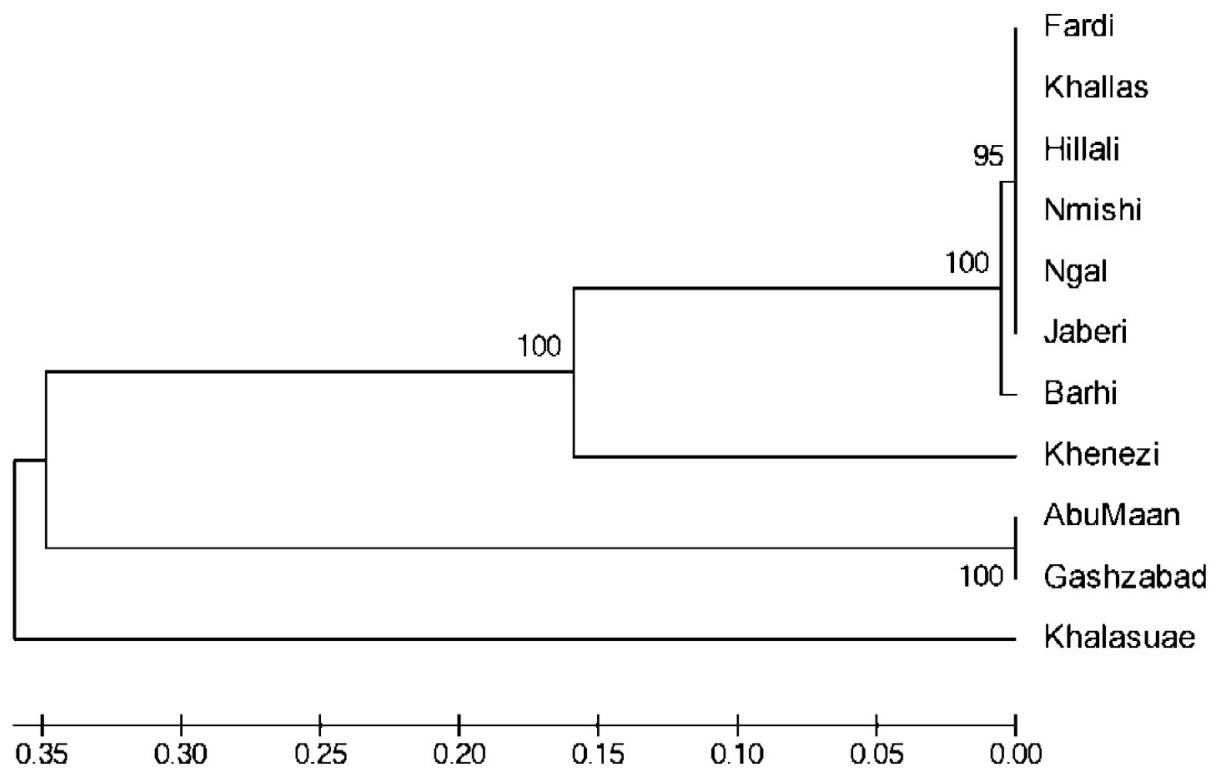

Figure 1. UPGMA tree based on Kimura 2-parameter of the matK. The branch support was assessed with 1000 replicates. The support values above $50 \%$ were shown.

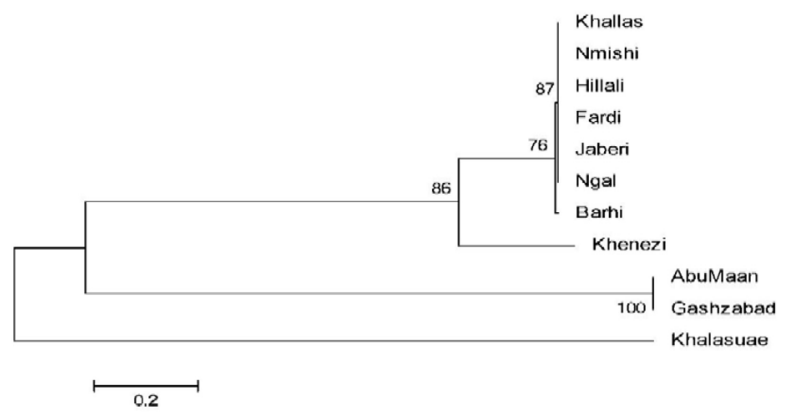

Figure 2. Maximum-likelihood tree constructed from nucleotide sequences of the mat $\mathrm{K}$ gene. Bootstrap values of the $50 \%$ majority rule are indicated and 1000 bootstrap replicates were used. 


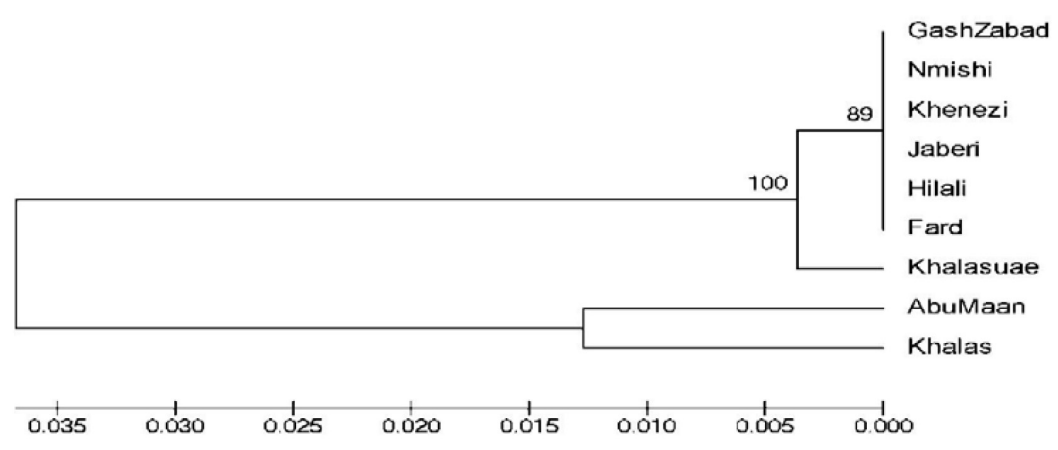

Figure 3. UPGMA tree based on Kimura 2-parameter of the rpoC1. The branch support was assessed with 1000 replicates. The support values above $50 \%$ were shown.

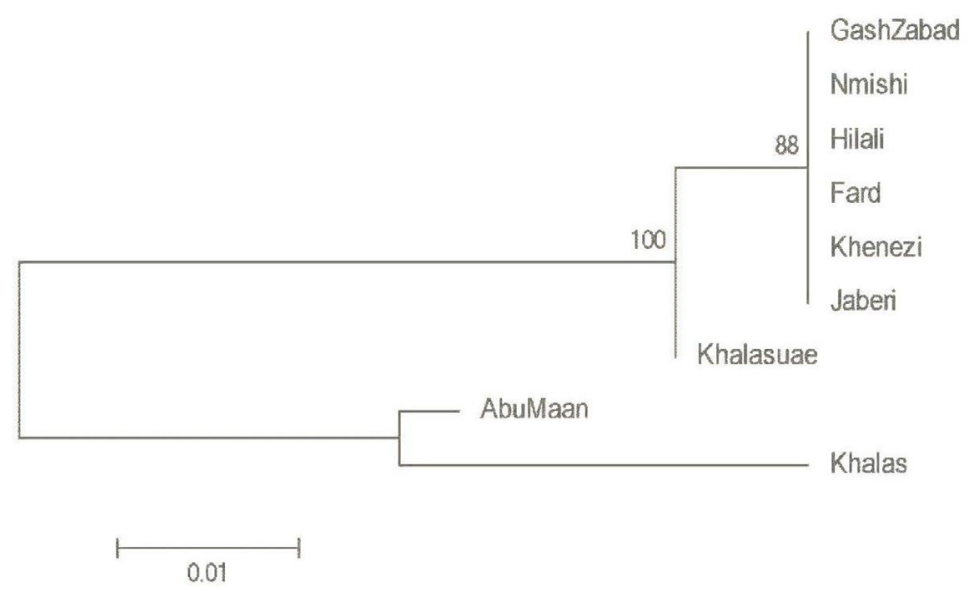

Figure 4. Maximum-likelihood tree constructed from nucleotide sequences of the rpoC1 gene. Bootstrap values of the $50 \%$ majority rule are indicated and 1000 bootstrap replicates were used.

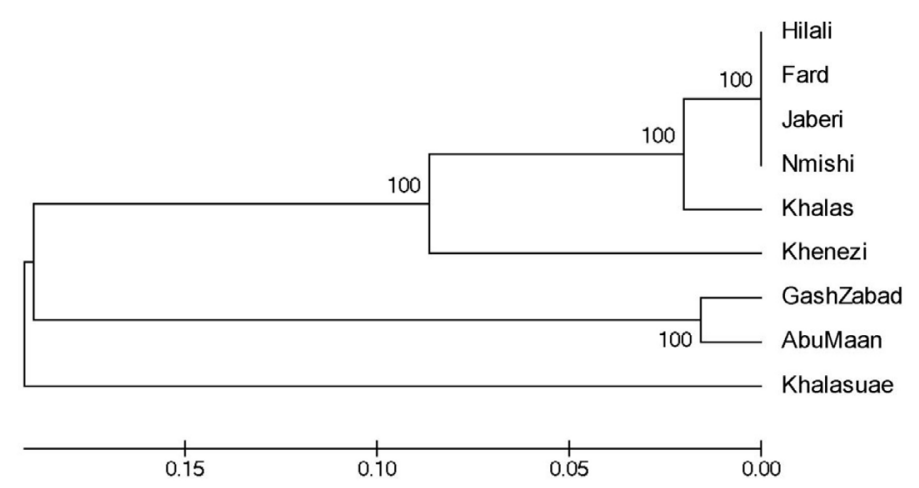

Figure 5. UPGMA tree based on Kimura 2-parameter using combined chloroplast loci (mat $\mathrm{K}+$ rpo 1 ). The branch support was assessed with 1000 replicates. The support values above $50 \%$ were shown. 


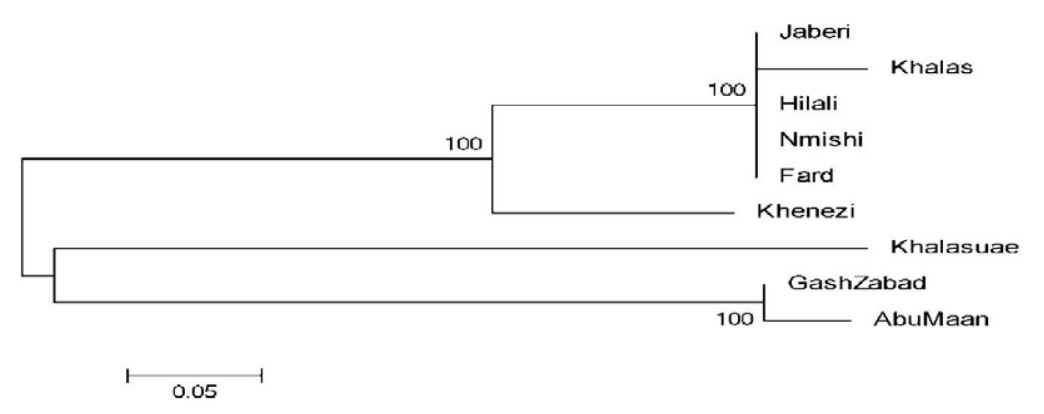

Figure 6. Maximum-likelihood tree constructed from nucleotide sequences using combined chloroplast loci (matK $+r p o \mathrm{C} 1)$. Bootstrap values of the $50 \%$ majority rule are indicated and 1000 bootstrap replicates were used.

Traditionally, cultivars and species were identified and characterized on the basis of morphological and physiological traits, which are sometimes difficult to discriminate (Kadkhodaei et al., 2010). DNA sequence-based identification is a more accurate method and has been used in many studies (Heinrich, 2008; Liu et al., 2011). The sequences generated in the present study, namely matK and $r p o \mathrm{C} 1$, were deposited in GenBank. All sequences had few variations in the percent of guanine plus cytosine content (\%GC) compared to that in the sequences of mat $\mathrm{K}$ and $r p o \mathrm{Cl}$ (Table 1). In the case of matK, the nucleotide composition was biased toward the guanine and cytosine content with frequencies of 30.4 to $34.8 \%$, respectively. In the case of $r p o C 1$, the $\% \mathrm{GC}$ content was 42.2 to $46.2 \%$ (Table 1). Similarly, Khan et al. (2012) found that the base composition of the rpoC1 gene sequence of Ochradenus species was $42-43 \%$. The generated sequences of mat $\mathrm{K}$ for date cultivars were compared with the generated sequences of rpoC1, and significant results were found in terms of sequence divergence. In this study, no insertions/deletions were found (InDels) either in matK or in $r p o \mathrm{C} 1$ (Figure S4). Similarly, no InDels were detected in the rpoC1 gene sequences of angiosperms (Samigullin et al., 1999). Internal spacers of the rpoC1 gene have been reported to have 6 base deletions and 11 base insertions (Khan et al., 2012). Lack of InDels in rpoC1 is attributed to its coding property, while the internal spacer of $r p o \mathrm{C} 1$ located in the non-coding region. The genetic distances among the 11 cultivars revealed by mat $\mathrm{K}$ sequences ranged from 0.00 to 0.722 (Table 2). The overall average distance $(0.375)$ was higher than that found with $r p o C 1$ $(0.0305$; Table 3$)$ or when the combination of $m a t \mathrm{~K}+r p o \mathrm{C} 1$ was used $(0.241$; Table 4$)$. Our data are in agreement with those of Rhouma et al. (2008), where the genetic distance exhibited values ranging from $0.10-0.76$ with mean of 0.34 in 40 date cultivars studied using random amplified microsatellite polymorphism markers. In the current study, for matK, the genetic distance (0.375) among date cultivars was more than 10 times that of the rpoC1 distance (0.0305). The corresponding parsimony informative characters ( 2 variants) were 94,17 , and 112 with $m a t \mathrm{~K}, r p o \mathrm{C} 1$, and $m a t \mathrm{~K}+r p o \mathrm{C} 1$, respectively, and the total number of mutations were 419,24 , and 441, respectively, and the numbers of variable sites were 278, 24, and 302, respectively (Table 5). The overall transition to transversion ratio was $0.54,0.51$, and 0.48 with $m a t \mathrm{~K}, r p o \mathrm{C} 1$, and combined $m a t \mathrm{~K}+r p o \mathrm{C} 1$ (Table 5). When the overall outputs of pairwise distance and tree analyses were compared, the latter strategy resulted in better resolution of cultivars. In our study, rpoC1 was considered to possess less cultivar-discriminating power than matK, possibly due to its minimal sequence variation (Hollingsworth et al., 2011). 
Table 2. Pairwise distance among the date palm cultivar revealed by matK.

\begin{tabular}{|c|c|c|c|c|c|c|c|c|c|c|c|}
\hline & Barhi & Ngal & Jaberi & Fardi & Hilali & Khenezi & Khalas & Abu Maan & Gashzabad & Nmishi & Khalasuae \\
\hline \multicolumn{12}{|l|}{ Barhi } \\
\hline Ngal & 0.01014 & & & & & & & & & & \\
\hline Jaberi & 0.01014 & 0.00000 & & & & & & & & & \\
\hline Fard & 0.01014 & 0.00000 & 0.00000 & & & & & & & & \\
\hline Hillali & 0.01014 & 0.00000 & 0.00000 & 0.00000 & & & & & & & \\
\hline Khenezi & 0.31757 & 0.31757 & 0.31757 & 0.31757 & 0.31757 & & & & & & \\
\hline Khallas & 0.01014 & 0.00000 & 0.00000 & 0.00000 & 0.00000 & 0.31757 & & & & & \\
\hline Abu Maan & 0.69932 & 0.69595 & 0.69595 & 0.69595 & 0.69595 & 0.70270 & 0.69595 & & & & \\
\hline Gashzabad & 0.69932 & 0.69595 & 0.69595 & 0.69595 & 0.69595 & 0.70270 & 0.69595 & 0.00000 & & & \\
\hline Nmishi & 0.01014 & 0.00000 & 0.00000 & 0.00000 & 0.00000 & 0.31757 & 0.00000 & 0.69595 & 0.69595 & & \\
\hline Khalasuae & 0.72297 & 0.71959 & 0.71959 & 0.71959 & 0.71959 & 0.71284 & 0.71959 & 0.72297 & 0.72297 & 0.71959 & \\
\hline
\end{tabular}

Overall average distance $=0.375$.

Table 3. Pairwise distance among the date palm cultivar revealed by $r p o \mathrm{C} 1$.

\begin{tabular}{lcccccccc}
\hline & Gashzabad & Nmishi & Hilali & Fard & Khenezi & Jaberi & Khalasuae & Abu Maan \\
\hline Gashzabad & & & & & & & & \\
Nmishi & 0.000 & & & & & & & \\
Hilali & 0.000 & 0.000 & & & & & \\
Fard & 0.000 & 0.000 & 0.000 & & & & \\
Khenezi & 0.000 & 0.000 & 0.000 & 0.000 & & & \\
Jaberi & 0.000 & 0.000 & 0.000 & 0.000 & 0.000 & & & \\
Khalasuae & 0.007 & 0.007 & 0.007 & 0.007 & 0.007 & 0.007 & & \\
Abu Maan & 0.069 & 0.069 & 0.069 & 0.069 & 0.069 & 0.069 & 0.061 & 0.026 \\
Khalas & 0.090 & 0.090 & 0.090 & 0.090 & 0.090 & 0.090 & 0.081 & 0.000 \\
\hline
\end{tabular}

Overall average distance $=0.0305$.

Table 4. Pairwise distance among the date palm cultivar revealed by combined matK and $r p o \mathrm{C} 1$ loci.

\begin{tabular}{lcccccccc}
\hline & Gashzabad & Nmishi & Hilali & Fard & Khenezi & Jaberi & Khalasuae & Abu Maan \\
\hline Gashzabad & & & & & & & & \\
Nmishi & 0.36077 & & & & & & & \\
Hilali & 0.36077 & 0.00000 & & & & & \\
Fard & 0.36077 & 0.00000 & 0.00000 & & & & \\
Khenezi & 0.36427 & 0.16462 & 0.16462 & 0.16462 & & & \\
Jaberi & 0.36077 & 0.00000 & 0.00000 & 0.00000 & 0.16462 & & & \\
Khalasuae & 0.37828 & 0.37653 & 0.37653 & 0.37653 & 0.37303 & 0.37653 & & \\
Abu Maan & 0.03152 & 0.39229 & 0.39229 & 0.39229 & 0.39580 & 0.39229 & 0.40280 & 0.37303 \\
Khalas & 0.40105 & 0.04028 & 0.04028 & 0.04028 & 0.20490 & 0.04028 & 0.40981 & \\
\hline
\end{tabular}

Overall average $=0.241$.

Table 5. Summary characteristic of the two chloroplast markers evaluated in this study.

\begin{tabular}{|c|c|c|c|c|c|c|c|c|c|}
\hline Marker & $\begin{array}{l}\text { Aligned } \\
\text { sequence } \\
\text { length }\end{array}$ & $\begin{array}{l}\text { Variable } \\
\text { sites (S) }\end{array}$ & $\begin{array}{c}\text { Percentage } \\
\text { parsimony } \\
\text { informative sites } \\
\text { (two variants) }\end{array}$ & $\begin{array}{l}\text { Nucleotide } \\
\text { diversity } \\
\text { (per site) }\end{array}$ & $\begin{array}{c}\text { Total number } \\
\text { of mutation } \\
\text { (Eta) }\end{array}$ & $\begin{array}{l}\text { Theta (per site ) } \\
\text { from Eta }\end{array}$ & $\begin{array}{c}\text { Theta (per site) } \\
\text { from } \mathrm{S}\end{array}$ & $\begin{array}{c}\text { Transition/ } \\
\text { transversion } \\
\text { bias }\end{array}$ & $\begin{array}{c}\text { Haplotype (gene) } \\
\text { diversity }\end{array}$ \\
\hline matK & 296 & 278 & 31.76 & 0.37525 & 419 & 0.48329 & 0.82427 & 0.54 & 0.709 \\
\hline rpoC1 & 275 & 24 & 6.18 & 0.03051 & 24 & 0.03211 & 0.03411 & 0.51 & 0.583 \\
\hline$m a t \mathrm{~K}+r p o \mathrm{C} 1$ & 571 & 302 & 19.61 & 0.24090 & 441 & 0.2841 & 0.30198 & 0.48 & 0.833 \\
\hline
\end{tabular}

The matK locus showed more polymorphic sites than the rpoC1 locus; hence, it was more informative and proved to be very effective in differencing the date palm cultivars. The matK locus has been shown to provide high level of species recovery in several plant DNA barcoding studies on different floristic or biodiversity hotspots (Kress and Erickson, 2007; Lahaye 
et al., 2008; CBOL, 2009; Chen et al., 2010) as in the present study. The genetic divergence evaluated among the date palm cultivars might be due to the dispersal of off-shoots, pollen grains, and seeds (Al-Qurainy et al., 2011a). Off-shoots and pollen grains are extensively distributed among farmers within a village, province, or country, while seed dispersal occurs by other means, such as via travelers and traders, across geographic borders (Elshibli and Korpelainen, 2008). The other reasons for sequence variability among the date cultivars could be due to the different mating frequencies, mutation rate, gene flow patterns, long-term evolution history, and human activities; these factors affect the genetic variation patterns among plant populations. Furthermore, environmental factors might be one of the reasons for variability (Nybom and Bartish, 2000). Haplotype (gene) diversity among date cultivars was $0.709,0.583$, and 0.833 with $m a t \mathrm{~K}, r p o \mathrm{C} 1$, and combined $m a t \mathrm{~K}+r p o \mathrm{C} 1$, respectively (Table 5 ). We found that the topology of phylogenetic trees constructed on the basis of $m a t \mathrm{~K}, r p o \mathrm{C} 1$, and $m a t \mathrm{~K}+r p o \mathrm{C} 1$ sequences were coherent with the number of haplotypes detected. The presence of more than one haplotype (Table S2) in the cultivars of Phoenix dactylifera from UAE might be explained as follows: a) the introduced cultivars had different origins; b) it originated from only one source, either through different introduction events or from a single event containing more than one haplotype. The local cultivar Khalasuae was separated as a single chloroplast haplotype. This might be explained by a unique introduction or multiple introductions of the same haplotype. Our results showed that the Khalasuae haplotype was not similar to khalas from Suadia Arabia. In conclusion, applying both nucleotide distance and phylogeny-based approaches, we found that matK locus, either singly or in combination, could discriminate date cultivars.

\section{ACKNOWLEDGMENTS}

We thank Dr. Khaled Amiri, Head of the Biology Department at United Arab Emirates University for his help and support.

\section{Supplementary material}

\section{REFERENCES}

Al-Khalifah NS and Askari E (2003). Molecular phylogeny of date palm (Phoenix dactylifera L.) cultivars from Saudi Arabia by DNA fingerprinting. Theor. Appl. Genet. 107: 1266-1270.

Al-Qurainy F, Khan S, Al-Hemaid FM, Ali MA, et al. (2011a). Assessing Molecular Signature for Some Potential Date (Phoenix dactylifera L.) Cultivars from Saudi Arabia, Based on Chloroplast DNA Sequences rpoB and psbA-trnH. Int. J. Mol. Sci. 12: 6871-6880.

Al-Qurainy F, Khan S, Tarroum M, Al-Hemaid FM, et al. (2011b). Molecular authentication of the medicinal herb Ruta graveolens (Rutaceae) and an adulterant using nuclear and chloroplast DNA markers. Genet. Mol. Res. 10: 2806-2816.

Asmussen C and Liston A (1998). Chloroplast DNA characters, phylogeny, and classification of Lathyrus (Fabaceae). Am. J. Bot. 85: 387.

Biglari F, AlKarkhi AFM and Easa AM (2008). Antioxidant activity and phenolic content of various date palm (Phoenix dactylifera) fruits from Iran. Food Chem. 107: 1636-1641.

Bulpitt CJ, Li Y, Bulpitt PF and Wang J (2007). The use of orchids in Chinese medicine. J. R. Soc. Med. 100: 558-563.

Burgess KS, Fazekas AJ, Kesanakurti PR, Graham SW, et al. (2011). Discriminating plant species in a local temperate flora using the $r b c L+$ matK DNA barcode. Meth. Ecol. Evol. 2: 333-340.

CBOL Plant Working Group (2009). A DNA barcode for land plants. Proc. Natl. Acad. Sci. U. S. A. 106: 12794-12797.

Chase MW, Salamin N, Wilkinson M, Dunwell JM, et al. (2005). Land plants and DNA barcodes: short-term and longterm goals. Philos. Trans. R. Soc. Lond B. Biol. Sci. 360: 1889-1895.

Chen S, Yao H, Han J, Liu C, et al. (2010). Validation of the ITS2 region as a novel DNA barcode for identifying medicinal plant species. PLoS One 5: e8613.

Devey DS, Chase MW and Clarkson JJ (2009). A stuttering start to plant DNA barcoding: microsatellites present a 
previously overlooked problem in non-coding plastid regions. Taxon 58: 7-15.

Elshibli S and Korpelainen H (2008). Microsatellite markers reveal high genetic diversity in date palm (Phoenix dactylifera L.) germplasm from Sudan. Genetica 134: 251-260.

Fazekas AJ, Burgess KS, Kesanakurti PR, Graham SW, et al. (2008). Multiple multilocus DNA barcodes from the plastid genome discriminate plant species equally well. PLoS One 3: e2802.

Fazekas AJ, Kesanakurti PR, Burgess KS, Percy DM, et al. (2009). Are plant species inherently harder to discriminate than animal species using DNA barcoding markers? Mol. Ecol. Resour. 9 (Suppl 1): 130-139.

Gao T, Sun Z, Yao H, Song J, et al. (2011). Identification of Fabaceae plants using the DNA barcode matK. Planta Med. 77: 92-94.

Hebert PD, Cywinska A, Ball SL and deWaard JR (2003). Biological identifications through DNA barcodes. Proc. Biol. Sci. 270: 313-321.

Heinrich M (2008). Ethnopharmacy and natural product research-multidisciplinary opportunities for research in the metabolomic age. Phytochem. Lett. 1: 1-5.

Hollingsworth PM, Graham SW and Little DP (2011). Choosing and using a plant DNA barcode. PLoS One 6: e19254.

Hosseini S, Go R, Dadkhah K and Nuruddin AA (2012). Studies on maturase k sequences and systematic classification of bulbophyllum in Peninsular Malaysia. Pak. J. Bot. 44: 2047.

Kadkhodaei S, Elahy M, Nekouei MK, Imani A, et al. (2010). A panel of cultivate specific marker based on polymorphisms at microsatellite markers for Iranian cultivated Almonds (Prunus dulcis). Aust. J. Crop Sci. 4: 730-736.

Khan S, Mirza KJ and Abdin MZ (2011). DNA fingerprinting for the authentication of Ruta graveolens. Afr. J. Biotechnol. 10: 8709-8715.

Khan S, Al-Qurainy F and Nadeem M (2012). Biotechnological approaches for conservation and improvement of rare and endangered plants of Saudi Arabia. Saudi J. Biol. Sci. 19: 1-11.

Kress WJ and Erickson DL (2007). A two-locus global DNA barcode for land plants: the coding rbcL gene complements the non-coding trnH-psbA spacer region. PLoS One 2: e508.

Kress WJ, Wurdack KJ, Zimmer EA, Weigt LA, et al. (2005). Use of DNA barcodes to identify flowering plants. Proc. Natl. Acad. Sci. U. S. A. 102: 8369-8374.

Lahaye R, van der Bank M, Bogarin D, Warner J, et al. (2008). DNA barcoding the floras of biodiversity hotspots. Proc. Natl. Acad. Sci. U. S. A. 105: 2923-2928.

Librado P and Rozas J (2009). DnaSP v5: a software for comprehensive analysis of DNA polymorphism data. Bioinformatics 25: 1451-1452.

Liu C, Gu Z, Yang W, Yang L, et al. (2011). Advances of biological taxonomy and species identification in medicinal plant species by DNA barcodes. J. Am. Sci. 7: 147-151.

Nybom H and Bartish IV (2000). Effects of life history traits and sampling strategies on genetic diversity estimates obtained with RAPD markers in plants. Perspect Plant Ecol. 3: 93-114.

Rhouma S, Dakhlaoui-Dkhil S, OuldMohamed Salem A and Zehdi Azouzi S (2008). Genetic diversity and phylogenic relationships in date-palms (Phoenixdactylifera L) as assessed by random amplified microsatellite polymorphism markers (RAMPOs). Sci. Hort. 117: 53-57.

Roy S, Tyagi A, Shukla V, Kumar A, et al. (2010). Universal plant DNA barcode loci may not work in complex groups: a case study with Indian berberis species. PLoS One 5: e13674.

Saafi EB, El-Arem A, Issaoui M and Hammami M (2009). Phenolic content and antioxidant activity of four date palm (Phoenix dactylifera L) fruit varieties grown in Tunisia. Int. J. Food Sci. 44: 2314-2319.

Samigullin TK, Martin WF, Troitsky AV and Antonov AS (1999). Molecular data from the chloroplast rpoC1 gene suggest a deep and distinct dichotomy of contemporary spermatophytes into two monophyla: gymnosperms (including Gnetales) and angiosperms. J. Mol. Evol. 49: 310-315.

Sass C, Little DP, Stevenson DW and Specht CD (2007). DNA barcoding in the cycadales: testing the potential of proposed barcoding markers for species identification of cycads. PLoS One 2: e1154.

Sedra MH, Lashermes P, Trouslot P and Combes M (1998). Identification and genetic diversity analysis of date palm (Phoenix dactylifera L.) varieties from Morocco using RAPD markers. Euphytica 103: 75-82.

Sghaier-Hammami B, Valledor L, Drira N and Jorrin-Novo JV (2009). Proteomic analysis of the development and germination of date palm (Phoenix dactylifera L.) zygotic embryos. Proteomics 9: 2543-2554.

Tamura K, Nei M and Kumar S (2004). Prospects for inferring very large phylogenies by using the neighbor-joining method. Proc. Natl. Acad. Sci. U. S. A. 101: 11030-11035.

Tamura K, Dudley J, Nei M and Kumar S (2007). MEGA4: Molecular Evolutionary Genetics Analysis (MEGA) software version 4.0. Mol. Biol. Evol. 24: 1596-1599.

Wojciechowski MF, Lavin M and Sanderson MJ (2004). A phylogeny of legumes (Leguminosae) based on analysis of the plastid matK gene resolves many well-supported subclades within the family. Am. J. Bot. 91: 1846-1862.

Yu J, Xue JH and Zhou SL (2011). New universal matK primers for DNA barcoding angiosperms. J. Syst. Evol. 49: 176-181.

Zehdi S, Trifi M, Billotte N, Marrakchi M, et al. (2004). Genetic diversity of Tunisian date palms (Phoenixdactylifera L.) revealed by nuclear microsatellite polymprohism. Hereditas 141: 278-287. 